\title{
FRP Reinforcement for Concrete Frame Buildings at Mexico City Around 1900 to 1960
}

\author{
Juan M. García Garduño ${ }^{1}$, Perla R. Santa Ana Lozada ${ }^{2}$ and Lucia G. Santa Ana \\ Lozada $^{3}$ \\ ${ }^{1}$ Faculty of Architecture, Universidad Nacional Autónoma de México, Av. Universidad 3000, \\ Ciudad de México, México, manuel.tolentino@live.com \\ ${ }^{2}$ Faculty of Architecture, Universidad Nacional Autónoma de México, Av. Universidad 3000, \\ Ciudad de México, México,psal@unam.mx \\ ${ }^{3}$ Faculty of Architecture, Universidad Nacional Autónoma de México, Av. Universidad 3000, \\ Ciudad de México, México, 1s1@unam.mx
}

\begin{abstract}
Mexico City is located at a seismic region with a complex soil. That condition had an impact on buildings and their conservation; it requires to know their structural state to control strain and cracks that could cause severe damages. To accomplish that objective this research contemplates the evaluation of concrete elements to propose an alternative to restraint antique concrete deformations using FRP system.
\end{abstract}

Keywords: Architecture, Reinforced Concrete, Plastic Flow, Textile Composites, Carbon Fiber.

\section{Introduction}

Construction has always been complicated as the city is located on a seismic region (Servicio Geológico Mexicano, 2017), which also has a subsistence ground (Marsal J. and Mazari, 2016); specially during 1940, when technical information about the city complex soil was starting to be studied, and new constructive methods were developed for skyscrapers. Specialized research on the geotechnical and seismic engineering started in 1955 and 1962, respectively; twelve years after the Mexico City building code was used for the construction, about 1942-1966. Thus, all RC structures built before 1960 have a probability of exhibiting some damage. The aging of RC structures could be accelerated due to soil and seismic stresses. Permanent axial load causes plastic flow on RC (Park and Paulay, 1988), creating disbalance between the load/stress distribution of the structural system and producing fissures, structural cracks, or increasing the one that exists (Muñoz and Mendoza, 2012). Another critical factor for $\mathrm{RC}$ frames built on seismic areas is ductility of columns, which is provided by reinforcing bars (rebars), but buildings constructed before 1970 are considered as nonductile (Al-Mahaidi and Kalfat, 2018) while their columns have not enough rebars to accomplish with current regulation codes (Moehle, 1997).

Today most of these 1940-1960 buildings are still operative. The aim of this project is to improve the structural performance of historic buildings without affecting their patrimonial integrity. To accomplish the last objective, this study proposes the use of Fiber Reinforced Polymers (FRP) as a rehabilitation/reinforcement system. This method is selected because if 
its correctly applied, FRP could increase RC life-service by improving ductility and control plastic flow (Metha and Monteiro, 1998; Park and Paulay, 1988). The following variables will be analyzed to confirm the hypothesis:

a) The evaluation of FRP composites attached to a standard concrete mix will be made while analyzing the adherence between phases and the performance of FRP;

b) Analysis of the adherence between FRP composite and old concrete specimen;

c) Comparison between the previous data obtained with a weathering reinforced concrete specimen

\section{Method and Materials}

For this research FRP method refers to the use of a composite material made with carbon fiber impregnated with epoxy resin, applied to rehabilitate a structural member (American Concrete Institute, 2008). Carbon fiber CF) is the most commonly type of concrete reinforcement sections because its range of tensile properties allows an acceptable mechanical performance between phases (Hull, 2010; Park S.-J. , 2018), its semi crystalline microstructure exhibit an tensile strength over 1200-2250 MPa (Teng, Chen, Smith and Lam, 2002). Wet lay-up is the preferable method to applied CF because it has major advantages for in situ installation wherefor CF sheet can adapt to complex geometries (Teng, et al, 2002). Composites materials are based on mechanical adherence ar

over the concrete sectio

adherence, it could be

thickness from $0.5 \mathrm{~mm}$

carbon tow sheet thus on
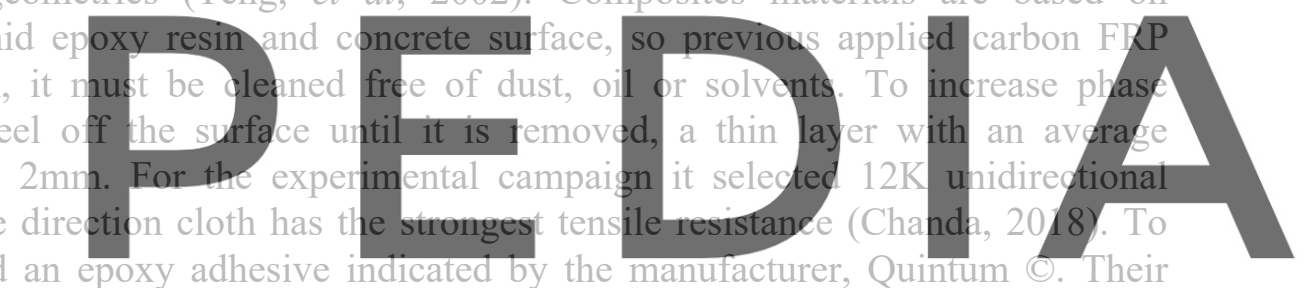

attach the fiber, it is used an epoxy adhechanical properties on Tables 1 and 2 .

Register for free at https//www.scipedia.com to download the version without the watermark

Table 1. Mechanical Properties of Carbon fiber.

\begin{tabular}{cccc}
\hline Material & Ultimate Tensile Strength & Young Modulus & Weight \\
\hline QuintumWrap-300@ & $875 \mathrm{MPa}$ & $34,500 \mathrm{MPa}$ & $302 \mathrm{~g} / \mathrm{m}^{2}$ \\
\hline
\end{tabular}

Mechanical properties of carbon fiber imbibed into epoxy resin. The cloth physical characteristics are: $0.5 \mathrm{~mm}$ thickness, $500 \mathrm{~mm}$ wide and $12 \mathrm{~K}$ tow.

Table 2. Mechanical Properties of Epoxy Resin.

\begin{tabular}{cccc}
\hline Material & $\begin{array}{c}\text { Compressive } \\
\text { Strength }\end{array}$ & $\begin{array}{c}\text { Lap shear Adhesion } \\
\text { Strength }\end{array}$ & Tensile Strength \\
\hline Q102R C & $121 \mathrm{MPa}$ & $12 \mathrm{MPa}$ & $42 \mathrm{MPa}$ \\
\hline
\end{tabular}

Epoxy adhesive is formed by two components: part A, bisphenol resin type and part B, ammonium adduct as hardener. Both shall mix in a $100 \mathrm{~g}: 10 \mathrm{gr}$ relation. 


\subsection{Manufacturing Specimens}

Concrete specimens were designed considering a structural resistance of 25Mpa (CEMEX) using the standards C192/C192M (ASTM, 2002). For the experimental campaign they were made six concrete cylinders of $150 \mathrm{~mm}$ radius and $300 \mathrm{~mm}$ height, using Portland Composite Cement (IMCyC, s.f.). Three of them were selected for control of the mix and three more for FRP reinforcement.

\subsection{Confined Concrete with Carbon Fiber}

After 20 days of demolding concrete cylinders, three specimens were prepared to attach CF by scabbling a $2 \mathrm{~mm}$ layer from the surface using an angle grinder. FRP method consisted of five steps that were made considering the combined action principle (Callister, 2009). The first step was applying a uniform layer of epoxy resin over the concrete surface. The second step was immersing the CF sheet ultimately into epoxy resin to reduce the air content and dry zones. The third step was wrapping to confining specimens with an impregnated fiber sheet with overlapping of 10 centimeters. The fourth step was removed the air trapped into the tows dragging a palette knife over the wrap. The fifth step was applied another uniform epoxy layer.
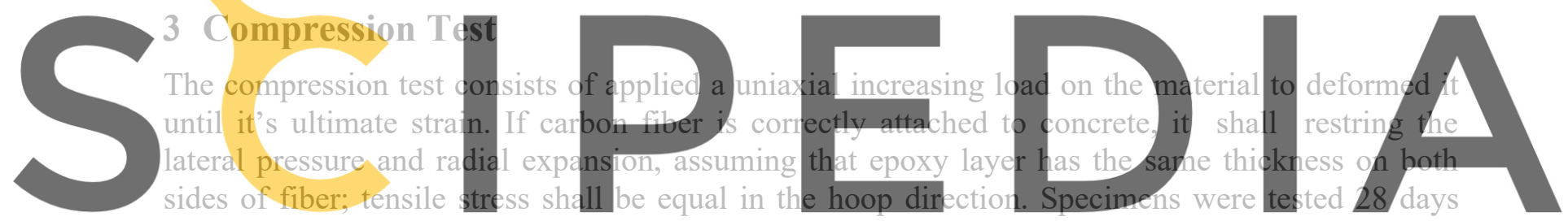

after manufacturing. Tests were made in an INTRON universal testing machine, screw-type

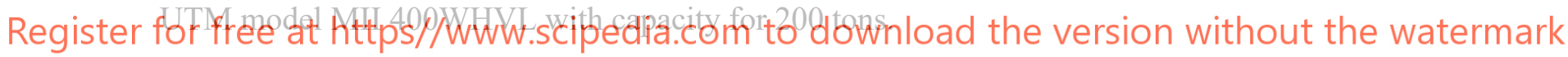

\section{Results}

Control specimens showed average compression strength of $22 \mathrm{MPa}$ and for the FRP it was an average strength over $38 \mathrm{MPa}$. CF almost doubled the compressive strength of concrete. In Table 3 shown test results.

Table 3. Results of compression test for Control and FRP specimens.

\begin{tabular}{cccc}
\hline Specimen & Maximal Load & $\begin{array}{c}\text { Ultimate Compression } \\
\text { Strength }\end{array}$ & Strain \\
\hline Control 1 & $38,514 \mathrm{kgf}$ & $21 \mathrm{MPa}$ & $2.1 \mathrm{~mm}$ \\
\hline Control 2 & $43,154 \mathrm{kgf}$ & $23.5 \mathrm{MPa}$ & $3.6 \mathrm{~mm}$ \\
\hline Control 3 & $39,791 \mathrm{kgf}$ & $21.7 \mathrm{MPa}$ & $2.9 \mathrm{~mm}$ \\
\hline FRP 1 & $65,914 \mathrm{kgf}$ & $36.5 \mathrm{MPa}$ & $5.1 \mathrm{~mm}$ \\
\hline FRP 2 & $66,235 \mathrm{kgf}$ & $36.7 \mathrm{MPa}$ & $5.2 \mathrm{~mm}$ \\
\hline FRP 3 & $73,090 \mathrm{kgf}$ & $40.5 \mathrm{MPa}$ & $5.5 \mathrm{~mm}$ \\
\hline
\end{tabular}


Table 3 shows the maximal values obtained from data bases of test machine.

Mechanical behavior of FRP specimens is shown in Figure 1. The three curves have a similar development with a semi-ductile trend, and all of them showed a small dropping when concrete reached its maximal compressive strength, as it is shown on figure 1 (left). All curves had the same geometrical composition, also, according with data in table 3: FRP 1-2 had a very similar mechanical behavior. On the other hand, FRP 3 continues growing asymmetric. The average FRP ratio was calculated using a sixth-grade polynomial trend line to correct each curve. After that, corrected data were put on the same base to define another trend line and made one more correction. The final result was the edited stress-strain curve, which had the average behavior of FRP specimens, it is shown in Figure 1 (right). Physical analysis shown in Figure 2-4.

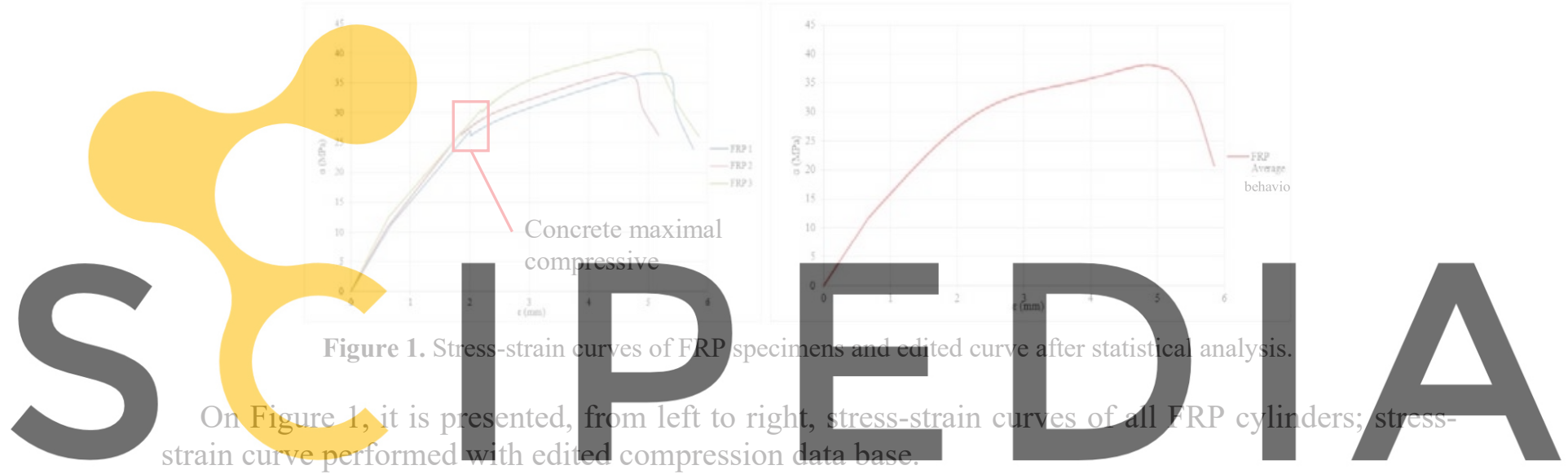

\section{Register for free at https//www.scipedia.com to download the version without the watermark}
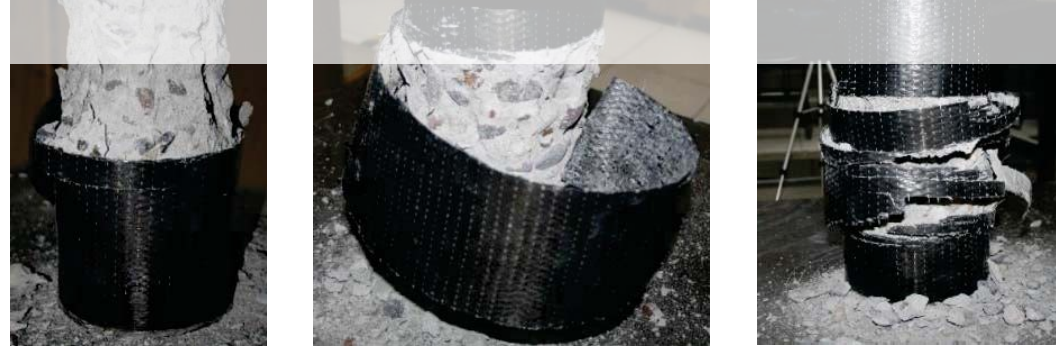

Figure 2. FRP specimens after compression test.

On Figure 2 it is shown, from left to right, FRP 1 with total detachment of CF; FRP 2, total detachment of CF; FRP 3, partial detachment of CF.

Specimens FRP 1 -2 failed because a delamination from overlap section, it shown on Figure $3 \mathrm{~A}$. The revision of the pulled off carbon layer showed the presence of a considerable quantity of voids at overlapping area, Figure 3B. While the rest had concrete residuum, Figure 3C. For those two cases, the matrix layers were detached because the distribution of stress was discontinuous 
due to voids. Internal stress at borders generated micro tangential tensions which broken the matrix, then shear produced by pressure delaminates the overlap. Concrete aggregate exposed refers to such good phase adhesion. According to the partial uniform state of the concrete section, specimens FRP 1-2 can not reached their ultimate compression strength; otherwise, residual concrete would be abundant cracks on the cylinder section; checking numerical data at Table 3 , load stress was transmitted by both phases only before delamination of FRP, after that each phase was working by itself: $\mathrm{CF}$ jacket was just restrung cylinder bulge until epoxy matrix was completely broken.
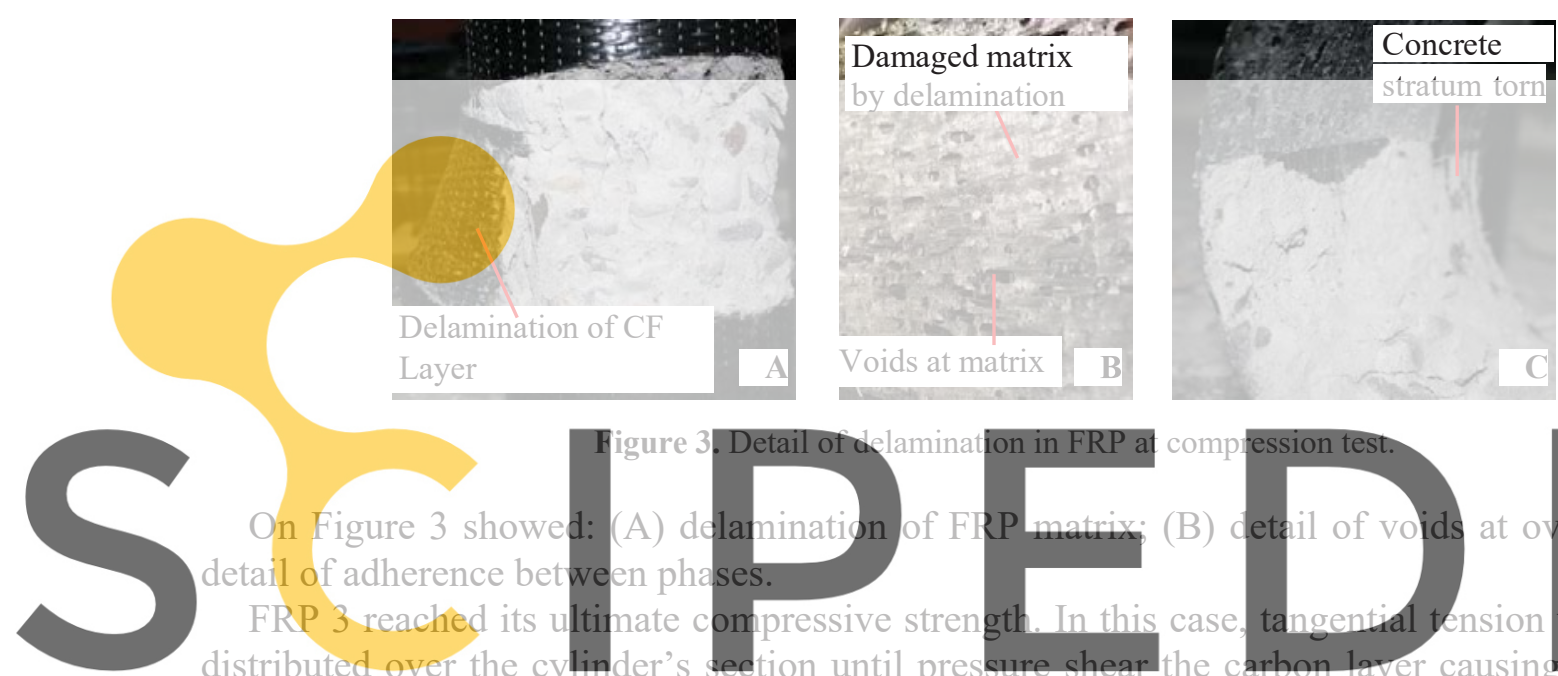

distributed over the cylinder's seetion until pres

The tested specimen had small delamination on overlap area, Figure 4D. Then, it assumes less

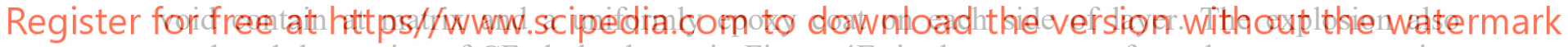
produced the tearing of CF cloth, shown in Figure 4E; it observes parts from the concrete section who were torn by the adhesive and remained attached to the epoxy matrix, Figure 4F. In FRP 3, serious cracks were caused by stress distribution, which means that when the concrete reached its maximal compressive strength, it still transmitting load. That indicates the simultaneous transmission of stress from both phases; this specimen already worked as a composite material.
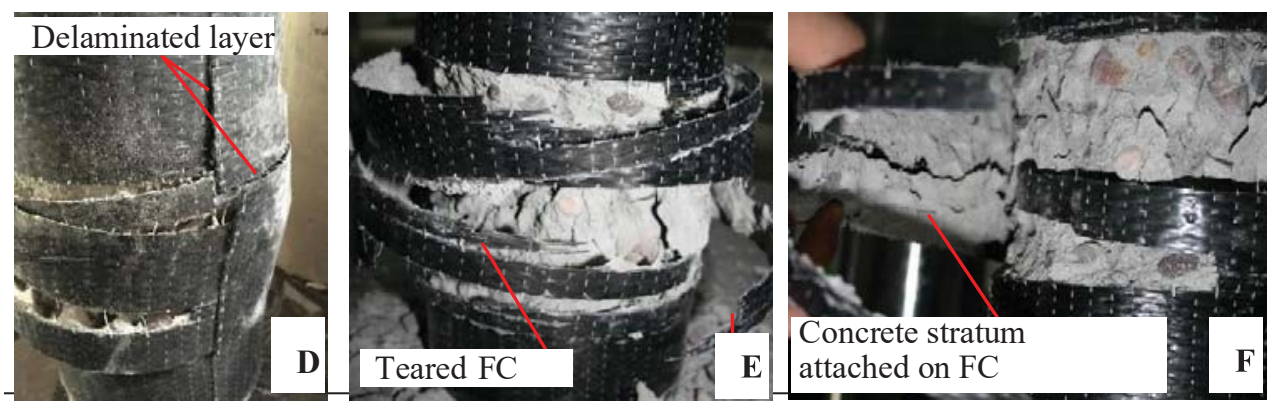

Figure 4. Detail of failure in FRP at compression test. 
On Figure 4 it can be seen: (D) Partial delamination of FRP matrix; (E) detail of CF teared by shear strength; (F) detail of adherence between phases.

Below its presented, on Figure 5, the results of concrete and FRP cylinders to contrast the influence of CF cloth. On this figure observes that carbon fiber actually extend the plastic zone of concrete allowing it major load resistance.

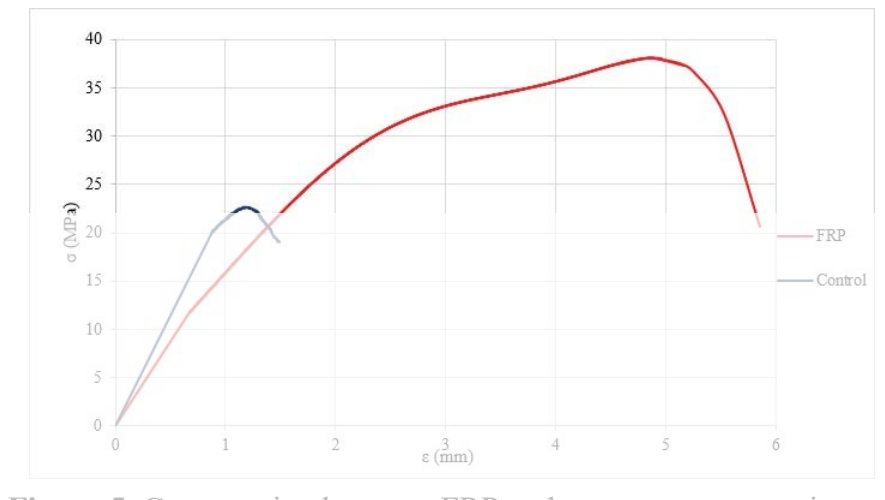

Figure 5. Comparation between FRP and pure concrete specimens.

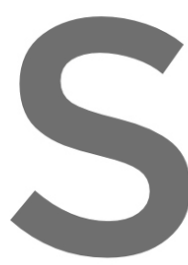

Based on the manual of SIKA (SIK A 2019), the theorical practical test results. O
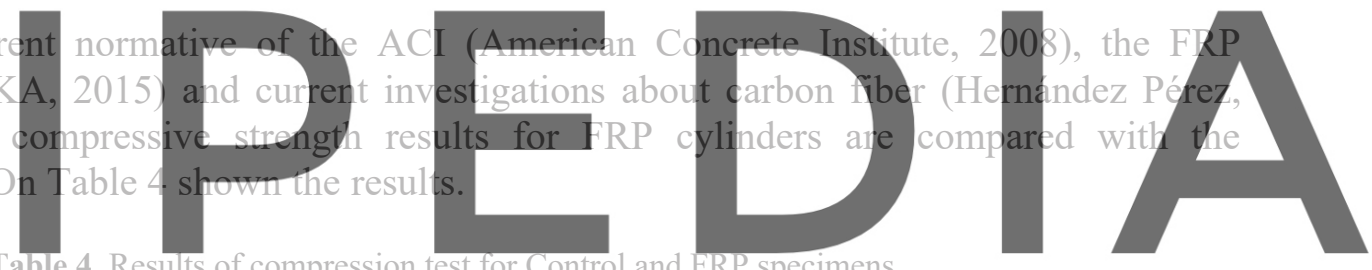

Table 4. Results of compression test for Control and FRP specimens.

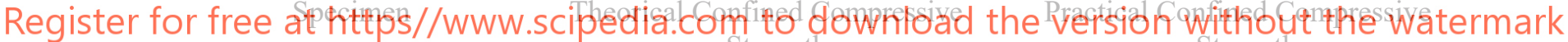

\begin{tabular}{lll}
\hline FRP 1 & $30.92 \mathrm{MPa}$ & $36.5 \mathrm{MPa}$ \\
\hline FRP 2 & $30.92 \mathrm{MPa}$ & $36.7 \mathrm{MPa}$ \\
\hline FRP 3 & $30.92 \mathrm{MPa}$ & $40.5 \mathrm{MPa}$ \\
\hline
\end{tabular}

Theorical confined compressive strength at table 4 only consider the design target compressive strength of $25 \mathrm{MPa}$ for the three specimens.

Comparison of numerical results at table 4 expressed an increment of $40 \%$ in practical tests compared with the theorical calculation, even with the cylinders whose FRP was detached.

\section{Conclusions}

- Based on the numerical data provided by the mechanical test, the method of manufacture, and the physic analysis of the FRP concrete specimens it concludes that the fiber reinforcement polymer method increases the compressive strength of concrete even if FRP is not well attached. This condition means that quality control at FRP application 
must be hardly supervised.

- The surface treatment had successful results on adherence between epoxy-concrete interphase. Mechanical adhesion between phases was strong to keep them together after radial pressure pull off the epoxy matrix. Considering that, significant attention must be put on overlapping while FRP method is applied. Delamination at this zone is the common cause of failure at confining, the matrix is easy to fracture by shear strength if there is a high void percent.

- The adherence range of service is such enough to control longitudinal and transversal deformation and consequently adding partial ductile properties. So then, carbon fiber is capable of retarding plastic deformation on concrete by full confining. The compression test is an accelerate process to deforming concrete until it is destroyed, then considering that plastic flow is a slow process it can conclude CF could stop deformation by aging. At service, FRP could produce some elasticity to concrete because its tensile resistance parallels to the axis. However, the characteristic of its materials still having a fragile trend. Under that premise, the porous matrix at the overlapping area is vulnerable to shear, torsion, impact, etc. As an optional experimental purpose to improve adherence in epoxyepoxy interphase, it could use a compatible polymeric adherence bridge.
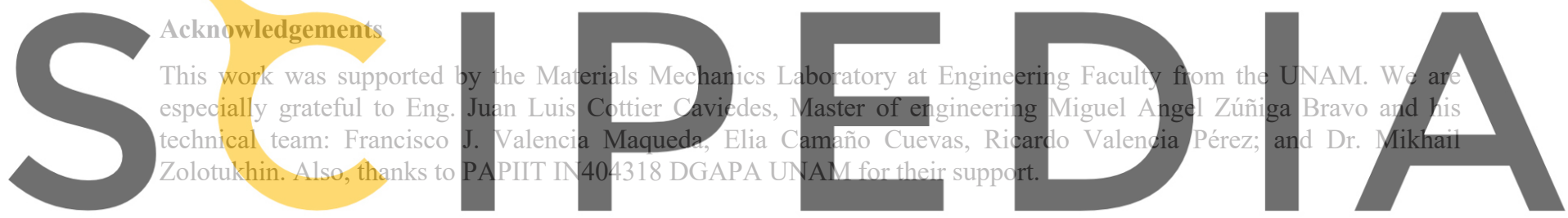

ORCIID

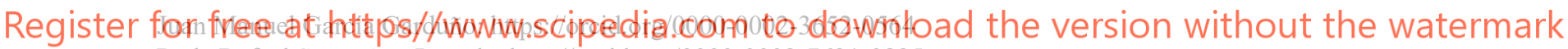

Perla Rafael Santa Ana Lozada: http://orcid.org/0000-0002-7631-0895

\section{References}

Administración Pública de la Ciudad de México (2017). Gaseta oficial de la Ciudad de México: Título Sexto, de la Seguridad Estructural de las Construcciones, Capitulo 1, Generalidades.

Al-Mahaidi, R. and Kalfat, R. (2018). Rehabilitation of Concrete Structures with Fiber-Reinforced Polymer.

Butterworth-Heinemann.

American Concrete Institute (2008). ACI 440.2R-08: Guide for the Design and Construction of Externally Bonded FRP Systems for Strengthening Concrete Structures. USA: American Concrete Institute.

ASTM (2002). C192/C192M-02 Srandard Practice for: Making and Curing Concrete Test Specimens in the Laboratory. American Society for Testing and Materials.

Callister, W. (2009). Introducción a la Ciencia e Ingeniería de Materiales. Ciudad de México: Limusa Wiley.

CEDEX (2010). http://www.cehopu.cedex.es/.

CEMEX. Manual del Constructor. CEMEX concretos.

Chanda, M. (2018). Plastics Technology Handbook. Florida, USA: CRC Press, Taylor \& Francis Group.

Hernández Pérez, M.E. (2019). Refuerzo y rehabilitación de especímenes de concreto con polímeros reforzados con fibra. Ciudad de México: UNAM. 
Hull, D. (2010). Materiales Compuestos. España: Editorial Reverté.

IMCyC (2010). Especial Bicentenario. Construcción y Tecnología en Concreto (271). http://www.imcyc.com/revistacyt/dic10/especial2.htm

IMCyC. http://imcyc.com. Obtenido de Guía de productos: concreto: Holcim Apasco: http://imcyc.com/ct2009/guiadeproductosjun09/concreto/holcimapasco.htm

Marsal J.R. and Mazari, M. (2016). El Subsuelo de la Ciudad de México. Ciudad de México: Instituto de Ingeniería UNAM.

Metha, P.K. and Monteiro, J.P. (1998). Concreto: Estructura, propiedades y materiales. Ciudad de Mexico: Instituto Mexicano del Cemento y el Concreto, A.C.

Moehle, J. (1997). State of research on seismic retrofit of concrete building structures in the US. Obtenido de http://www.ironwarrior.org/ARE/Lateral_Forces/us-japan_rehab_paper\%20Seismic\%20Retrofit.pdf

Muñoz, S.F. and Mendoza, E.C. (2012). La Durabilidad en las Estructuras de Concreto Reforzado des de la Perspectiva de la Norma Española para Estructuras de Concreto. Concreto y Cemento. Investigación y Desarrollo, 4(1), 63-86. https://www.redalyc.org/pdf/3612/361233551004.pdf

Organo del Gobierno Constitucional de los Estados Unidos Mexicanos (1942). http://www.smie.org.mx. Información técnica/reglamentos de construcción/Distrito Federal:

http://www.smie.org.mx/layout/reglamentos- construccion/distrito-federal-reglamento-construccion-estatal1942.pdf

Park, R. and Paulay, T. (1988). Estructuras de Concreto Reforzado. Ciudad de México: Editorial Limusa. S.A. de C.V.

Park, S.J. (2018). Carbon Fibers. Korea: Springer.

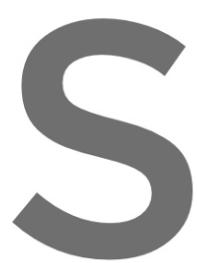

Servicio Geológico

https://www.sgm.gob.1

SIKA. (2015). Guía de

SIKA.

Teng, J., Chen, J., Smith, \$. and

Sons.Ltd.
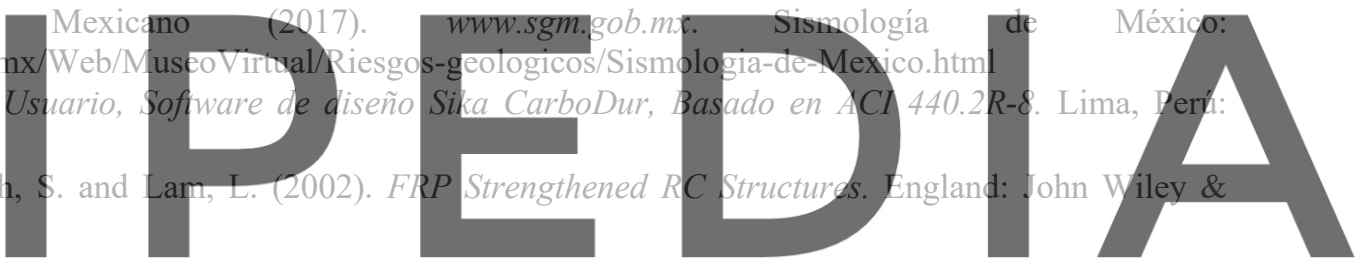

Register for free at https//www.scipedia.com to download the version without the watermark 